Dept. of Food Hygiene,

Fac. of Vet. Med.,

Assiut Univ.

\title{
"Prevalence of Arcobacter species in shell hens' eggs sold in Assiut Governorate"
}

(With 5 Tables)

By

\section{Nagah M. Saad and Enas El-Prince \\ "مدى انتشار أنواع الأركوباكتر فى بيض الاجاج المباع بمحافظة أسيوط"

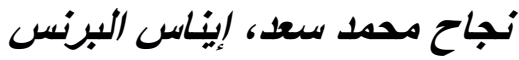

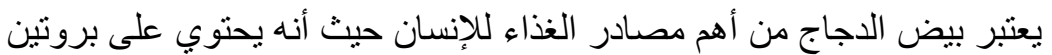

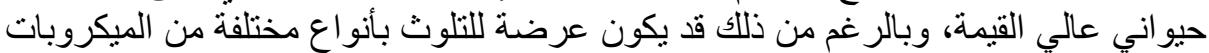

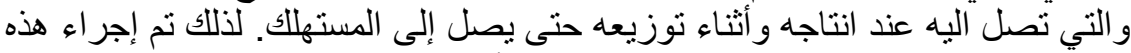

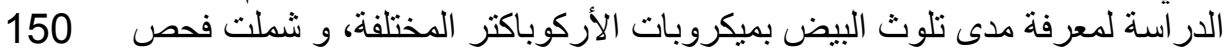

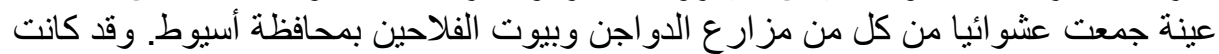

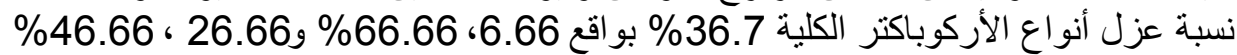

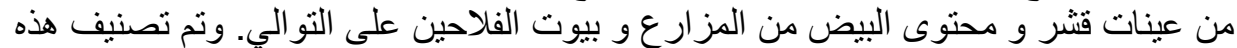

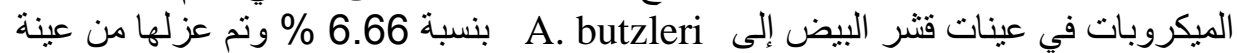

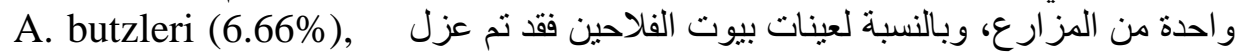
A. A. cryaerophilus (46.66\%), A. skirrowii (13.33\%)

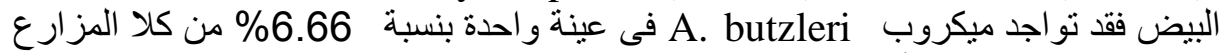

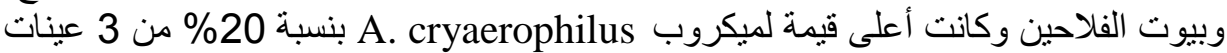

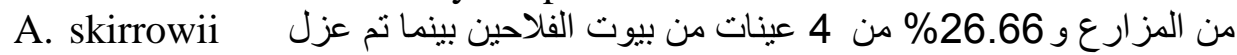

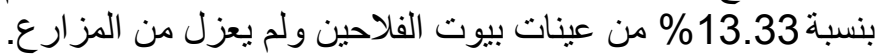

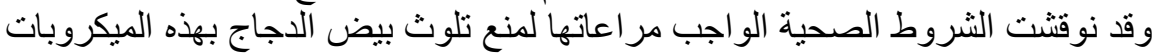
بالإضافة الى تحسين جودنه.

\section{Summary}

One hundred and fifty commercial shell hens' eggs (30 groups) were collected at random from farmers' houses and poultry farms (15 groups each) in Assiut Governorate and examined for the prevalence of Arcobacter species. The obtained results revealed that Arcobacter species were isolated from 11(36.7\%) samples of each egg shells and contents. These microorganisms were recovered from 6.66 and $66.66 \%$ of egg shell samples collected from farms and farmers houses, respectively. A. butzleri $(6.66 \%)$ was the only species that could be isolated from farms samples, while, A. butzleri, A. cryaerophilus and A. skirrowii were detected in percentages of 6.66, 46.66 and $13.33 \%$ from 
egg shell samples of farmers' houses. A. cryaerophilus was the most prevalent species followed by A. skirrowii and A. butzleri in samples of farmers' houses. In case of egg contents samples, the incidence of Arcobacters was $26.66 \%$ for farms and $46.66 \%$ for farmers' houses. Also, it is evident that A. butzleri was detected in $6.66 \%$ of egg contents samples collected from both farms and farmers houses. The higher percentage was related to A. cryaerophilus which isolated from 20.0 and $26.66 \%$ of the examined samples, respectively. A. skirrowii ranked second comprising $13.33 \%$ of egg contents samples of farmers' houses. The public health implications and suggestive measures for improving the hens' eggs quality were discussed.

Key words: Prevalence, Arcobacter species, shell hens' egg, Assiut Governorate.

\section{INTRODUCTION}

Hen egg is one of the first multifunctional food products. Its role in the human nutrition is decisively essential since eggs have been an important nutrient source for mankind for thousands of years. Eggs provide an excellent, inexpensive and low caloric source of high quality proteins. Eggs are also a good source of several important nutrients including folic acid, choline, iron, selenium and vitamins A, B, D, E and $\mathrm{K}$ (Kerver et al., 2002). They are also a good source of the antioxidant carotenoids, lutein and zeoxanthin (Davies and Reeves, 2002). The high nutritional properties of eggs make them ideal for many people with special dietary requirements. However, the nutrients that make eggs high quality food for human are also good growth medium for bacteria (Frazier and Westhoff, 1978).

The genus Arcobacter has become increasingly important in recent decades because its members can act as emergent enteropathogens and/or potential zoonotic agents (Ho et al., 2006 and Snelling et al., 2006). This genus is considered an atypical group within epsilon subdivision of the proteobacteria by the wide diversity of habitats and hosts where they can found (Debruyne et al., 2008).

Arcobacter contains ten species, A. butzleri, A. cryaerophilus, A. skirrowii, A. cibarius, A. nitrofragilis, A. halophilus (Houf et al., 2005). Very recently three new species have been added to the genus, A. mytili (Callado et al., 2009 a), A. thereius (Houf et al., 2009), finally, A. marinus (Kim et al., 2010). This new species enlarged the genus to nine validly published and the not yet established species candidates $\mathrm{A}$. 
sulfidiens have been isolated from a variety of sources but not from human yet (Sievert et al., 2007). The first 4 species have been associated with animals and humans (Van Driessche et al., 2004). A. butzleri is the most important and prevalent species of the genus and has been classified as a serious hazard to human health by the International Commission on Microbiological Specifications for Foods (ICMSF, 2002). It is usually associated with persistent watery diarrhoea and less often with more serious bloody diarrhoea, accompanied by symptoms of abdominal pains, nausea, vomiting and fever (Vandenberg et al., 2004). Moreover, it has also been found in cases of human extraintestinal disease, as it leads to peritonitis and endocarditis (Carter and Darla, 2004).

In animals, Arcobacters have been implicated in abortion, mastitis and gastrointestinal disorders but have also been recovered from asymptomatic animals (Vandamme et al., 1992 and Van Driessche et al., 2003).

Food products of animal origin have been suggested as an important potential transmission route of Arcobacter (Ho et al., 2006). Most studies on the prevalence Arcobacter in foods are on poultry (with the highest prevalence) followed by pork and beef products (Lehner et al., 2005 and Callado et al., 2009 b). Studies in foods have shown that, A. butzleri is the most prevalent species followed by A. cryaerophilus and A. skirrowii as reviewed by Lehner et al.(2005). Recently, Ho et al. (2008) found a high prevalence of Arcobacter in the intestinal content of poultry and the isolates recovered from the content of the gut and from the carcasses of the same flock had a similar genotype. In addition, it has been demonstrated that the intestinal tract and oviduct of breeding hens can be infected with Arcobacter (Lipman et al., 2008), although no evidence was found for transmission from hens to eggs. Arcobacter species may play a role in human and animal diseases, so this work aims to study their incidence in shell hens' eggs.

\section{MATERIAL AND METHODS}

Collection of samples

One hundred and fifty commercial shell hens' eggs (30 groups) were collected at random from farmers' houses and poultry farms (15 groups each) in Assiut Governorate. Every 5 eggs (one group) were placed in a sterile plastic bag and dispatched to the laboratory with a 
minimum of delay where they were prepared and examined for the prevalence of Arcobacter species.

Preparation of samples:

A- Egg shells:- Egg shells were tested by a surface rinse method as described by Moats (1979).

B- Egg contents:- eggs were prepared for evacuation of its contents according to Speck (1976).

Enrichment procedure:

One $\mathrm{ml}$ of rinse solution as well as from the homogenous egg contents was aseptically inoculated into a sterile test tube containing 10 $\mathrm{ml}$ of enrichment broth, Arcobacter selective broth (ASB) (Oxoid, CM0965) with Cefoperazone-Amphotericin-Teicoplain (CAT) selective supplement (Oxoid, SR174E) as described by Houf et al. (2003). The inoculated tubes were incubated at $28^{\circ} \mathrm{C}$ for $24-48 \mathrm{~h}$ in a $\mathrm{CO} 2$ incubator (Hera Cell 150) $(6 \% \mathrm{O} 2,10 \% \mathrm{CO} 2$ and $84 \% \mathrm{~N} 2)$ to provide a microaerophilic atmosphere.

Isolation and identification:

Inoculated broth cultures were streaked on Arcobacter selective agar (ASA) supplemented with CAT supplement (Houf et al., 2003). Streaked ASA plates were incubated at $28^{\circ} \mathrm{C}$ for $48-72 \mathrm{~h}$ under microaerophilic condition as described before. The isolated colonies were identified according to Atabay et al. (1998).

\section{Results}

The obtained results were recorded in Tables 1-5.

\section{Discussion}

The results recorded in Table 1 showed that Arcobacter species were isolated from $11(36.7 \%)$ out of the total 30 egg shell samples examined comprising 6.66 and $66.66 \%$ of samples collected from farms and farmers houses, respectively.

As seen from Table 2, the isolates recovered from egg shell samples were identified as A. butzleri $(6.66 \%)$ which is the only species that could be isolated from farms samples, while, A. butzleri, A. cryaerophilus and A. skirrowii were detected in percentages of 6.66, 46.66 and $13.33 \%$ from egg shell samples of farmers' houses. This study indicated that A. cryaerophilus was the most prevalent species followed 
by A. skirrowii and A. butzleri in the examined samples of farmers houses.

Eggs can be contaminated with various types of microorganisms from numerous sources as the faecal matter, the lining of the nest, wash water if the egg was washed, and handling and perhaps by the material in which eggs are packed (Board and Fuller, 1994 and Cox et al., 2000). It has been suggested that water may play an important role in transmission of these organisms (Rice et al., 1999).

Arcobacters have been isolated more frequently from poultry than from red meat (Corry and Atabay, 2001). Thus, poultry may be a significant reservoir of Arcobacter species.

The recovery rate of Arcobacters from total egg contents samples was $36.7 \%$ constituting $26.66 \%$ for farms and $46.66 \%$ for farmers houses (Table 1). Lipman et al. (2008) failed to detect Arcobacter species in the examined egg samples.

In this study, concerning the results in Table 4 it is evident that A. butzleri was detected in $6.66 \%$ of egg contents samples collected from both farms and farmers houses. The higher percentage was related to A. cryaerophilus which could be isolated from 20.0 and $26.66 \%$ of the examined samples, respectively. A. skirrowii ranked second in the number of cases of isolation comprising $13.33 \%$ of the examined egg contents samples from farmers' houses. Zanetti et al. (1996) could not isolate A. butzleri from the examined egg samples.

It has been documented that the storage of eggs at the sale outlets depending on storage conditions, particularly the temperature and duration, may affect the microbial load of both egg shell and contents but not the prevalence of bacteria (Jones et al., 2004).

The isolation of Arcobacters from farm hens' eggs is reported and alerts for the need to avoid contamination including environmental contamination and adopting the hygienic measures for eggs production. Beside the control measures at different stages of processing, an important step in controlling Arcobacters is to adequately cook eggs. Research must continue to collect critical epidemiological information on how Arcobacter survives and transmits in foods. Improving our understanding of key epidemiological issues related Arcobacter transmission will certainly improve our chances of sources in controlling this pathogen.

\section{REFERENCES}


Atabay, H. I.; Corry, J. and On, S. (1998): Diversity and prevalence of Arcobacter species in broiler chickens. J. Appl. Microbiol., 84: 1007-1016.

Board, R. G. and Fuller, R. (1994): Microbiology of the Avian Eggs. $1^{\text {st }}$ ed., Chapman \& Hall, pp.: 94-112, 128.

Callado, L.; Cleenwerck, I.; van Trappen, S.; De Vos, P. and Figueras, M. J. $(2009 a)$ : Arcobacter mytili sp. nov., an indoxyl acetatehydrolysis-negative bacterium isolated from mussels. Int. J. Syst. Evol. Microbiol. 59, 1391-1396.

Callado, L.; Gaurro, J. and Figueras, M. J. (2009 b): Presence of Arcobacter in meat and shellfish. J. Food Prot., 72: 1102-1106.

Carter, G. R. and Darla, J. W. (2004): Lawsonia, Campylobacter, Arcobacter and Helicobacter. In: Essential of Veterinary Bacteriology and Mycology Book. $6^{\text {th }}$ ed. pp.: 155-159, Law state Press.

Corry, J.E.L. and Atabay, H.I. (2001): Poultry as a source of Campylobacter and related organisms. J. Appl. Microbiol., 90: 965-1145.

Cox, N. A.; Berrang, M. E. and Cason, J. A. (2000): Salmonella penetration of egg shells and proliferation in broiler hatching eggs. A review. Poult. Sci., 79: 1571-1574.

Davies, C. and Reeves, R. (2002): High value opportunities from the chicken egg. RIRDC Publication No. 02/094, http:/www. rirdc. Gov. Au/reports/EGGS/02/094 sum.html.

Debruyne, L.; Gevers, D. and Vandamme, P. (2008): Taxonomy of the Family Campylobactereaceae. In: Campylobacter. $3^{\text {rd }}$ ed., Nachamkin, I.; Szymanski, C. and Blaser, M. pp.: 3-25, Washington, DC: ASM Press.

Frazier, W. C. and Westhoff, D. C. (1978): Contamination, preservation and spoilage of eggs. In: Food Microbiology, $3^{\text {rd }}$ ed., TATA McGraw Hill INC., pp.: 256-269.

Ho,T. K.; Lipman, L. J. and Gaastra, W. (2006): Arcobacter, what is known and unknown about a potential foodborne zoonotic agent. Vet. Microbiol., 115: 1-13.

Ho, H. T.; Lipman, L. J. and Gaastra, W. (2008): The introduction of Arcobacter species in poultry slaughter houses. Int. J. Food Microbiol., 125: 223-229.

Houf, K.; De Zutter, L.; Verbeke, B.; Van Hoof, J. and Vandamme, P. (2003): Molecular characterization of Arcobacter isolates collected in a poultry slaughter house. J. Food Prot., 66: 364-369. 
Houf, K., On, S.; Coenye, T.; Debruyne, L.; De Smet, S. and Vandamme, P. (2009): A. thereius sp. nov., isolated from pigs and duck. Int. J. Syst. Evol. Microbiol., 59 (10): 2599-2604.

Houf, K., On, S.; Coenye, T.; Mast, J.; Van Hoof, J. and Vandamme, P. (2005): A. cibarius sp. nov., isolated from broiler carcases. Int. J. Syst. Evol. Microbiol., 55: 713-717.

ICMSF “International Commission on Microbiological Specifications for Foods" (2002): Microorganisms in foods, Microbiological Testing in Food Safety Management. Kluwer Academic/Plenum Publ., New York.

Jones, D. R.; Curtis, P. R. and Anderson, K. E. (2004): Microbial contamination in inoculated shell eggs. 1 l. Effect of layer strain and egg storage. Poult. Sci., 74: 753-757.

Kerver, J. M.; Parh, Y. and Song, W. O. (2002): The role of eggs in American diets: health implications and benefits. In: Eggs and Health Promotion. Watson, R. (Ed.), Blackwell Publ. Co., Iowa State Press, USA.

Kim, H. M.; Hwang, C. Y. and Cho, B. C. (2010): A. marinus sp. nov. Int. J. Syst. Evol. Microbiol., 60(3): 531-536.

Lehner, A.; Tasara, T. and Stephan, R. (2005): Relevant aspect of Arcobacter species as potential foodborne pathogen. Int. J. Food Microbiol., 102: 127-135.

Lipman, L.; Ho, H. and Gaastra, W. (2008): The presence of Arcobacter species in breeding hens and eggs from these hens. Poult. Sci., 87(11): 2404-2407.

Moats, W. A. (1979): The effect of washing eggs under commercial conditions on bacterial loads on egg shells. Poult. Sci., 58: 12281233.

Rice, E.W.; Rodgers, M. R.; Wesley, I. V.; Johnson, C. H. and Tanner, S. A. (1999): Isolation of A. butzleri from ground water. Lett. Appl. Microbiol., 28: 31-35.

Sievert, S. M.; Wieringa, A. B. A.; Wirsen, E. D. and Taylor, C. D. (2007): Growth and mechanism of filamentous-sulfer formation by candidates Arcobacter sulfidius in opposing oxygen-sulfide gradients. Environ. Microbiol., 9(1): 81-92.

Snelling, W. J.; Matsuda, M.; Moore, J. E. and Dooley, J. S. (2006): Under the microscope: Arcobacter. Lett. Appl. Microbiol., 42: 714. 
Speck, M. L. (Ed.) (1976): Compendium of Methods for the Microbiological Examination of Foods. American Public Health Association, Washington, DC.

Vandamme, P.; Van Canneyt, M.; Pot, B.; Meis, L.; Hoste, B.; Dewettinck, D.; Vlaes, L.; Vanden Borre, C.; Hommez, J.; Kersters, K.; Butzler, J. and Goossens, H. (1992): Polyphasic taxonomic study of the amended genus Arcobacter with A. butzleri comb. nov. and A. skirrowii sp. nov., an aerotolerant bacterium isolated from veterinary specimens. Int. J. Syst. Bacteriol., 42: 344-356.

Vandenberg, O.; Dediste, A. and Houf, K. (2004): Arcobacter species in humans. Emerging Infec. Dis., 10: 1863-1867.

Van Driessche, E.; Houf, K.; Van Hoof, J.; De Zutter, L. and Vandamme, P. (2003): Isolation of Arcobacter species from animal faeces. FEMS Microbiol. Lett., 229: 243-248.

Van Driessche, E.; Houf, K.; De Zutter, L. and Van Hoof, J. (2004): Occurrence and strain diversity of Arcobacter species isolated from healthy Belgian pigs. Res. Microbiol., 155: 662-666.

Zanetti, F.; Varoli, O.; Stampi, S. and Deluca, G. (1996): Prevalence of thermophilic Campylobacter and A. butzleri in food of animal origin. Int. J. Food Microbiol., 33: 315-321.

Table 1: Incidence of Arcobacter species recovered from the examined shell eggs samples

\begin{tabular}{|l|c|c|c|c|c|}
\hline \multirow{2}{*}{$\begin{array}{c}\text { Source of } \\
\text { samples }\end{array}$} & \multirow{2}{*}{$\begin{array}{c}\text { No. of } \\
\text { examined }\end{array}$} & \multicolumn{2}{c|}{ Egg shell } & \multicolumn{2}{c|}{ Egg content } \\
\cline { 3 - 6 } & samples & \multicolumn{2}{c|}{ Positive samples } & \multicolumn{2}{c|}{ Positive samples } \\
\cline { 3 - 6 } & 15 & 1 & $6.66 \%$ & 4 & $26.66 \%$ \\
\hline Farms & 15 & 10 & $66.66 \%$ & 7 & $46.66 \%$ \\
Farmers & & & & & \\
houses & 30 & 11 & $36.7 \%$ & 11 & $36.7 \%$ \\
\hline Total & & \multicolumn{4}{|c}{} \\
\hline
\end{tabular}

Table 2: Incidence of different isolated strains of Arcobacter species from the examined egg shell samples

\begin{tabular}{|l|c|c|c|c|}
\hline \multirow{2}{*}{ Source } & \multicolumn{2}{|c|}{ Farms } & \multicolumn{2}{c|}{ Farmers houses } \\
\cline { 2 - 5 } Isolated strains & No./15 & $\%$ & No./15 & $\%$ \\
\hline A.butzleri & 1 & $6.66 \%$ & 1 & $6.66 \%$ \\
A. cryaerophilus & - & - & 7 & $46.66 \%$ \\
\hline
\end{tabular}


Assiut Vet.Med.J. Vol.57No.130July 2011

\begin{tabular}{|l|l|l|l|l|}
\hline A.skirrowii & - & - & 2 & $13.33 \%$ \\
\hline
\end{tabular}

Table 3: Frequency distribution of different isolated strains of Arcobacter species from the examined egg shell samples

\begin{tabular}{|l|c|c|c|c|}
\hline \multirow{2}{*}{ Source } & \multicolumn{2}{|c|}{ Farms } & \multicolumn{2}{c|}{ Farmers houses } \\
\cline { 2 - 5 } Isolated strains & No./1 & $\%$ & No./10 & $\%$ \\
\hline A.butzleri & 1 & $100.0 \%$ & 1 & $10.0 \%$ \\
A. cryaerophilus & - & - & 7 & $70.0 \%$ \\
A.skirrowii & - & - & 2 & $20.0 \%$ \\
\hline Total & 1 & $100.0 \%$ & 10 & $100.0 \%$ \\
\hline
\end{tabular}

Table 4: Incidence of different isolated strains of Arcobacter species from the examined egg content samples

\begin{tabular}{|l|c|c|c|c|}
\hline \multirow{2}{*}{ Source } & \multicolumn{2}{|c|}{ Farms } & \multicolumn{2}{c|}{ Farmers houses } \\
\cline { 2 - 5 } Isolated strains & No./15 & $\%$ & No./15 & $\%$ \\
\hline A.butzleri & 1 & $6.66 \%$ & 1 & $6.66 \%$ \\
A. & 3 & $20.00 \%$ & 4 & $26.66 \%$ \\
cryaerophilus & - & - & 2 & $13.33 \%$ \\
A.skirrowii & & & & \\
\hline
\end{tabular}

Table 5: Frequency distribution of different isolated strains of Arcobacter species from the examined egg content samples

\begin{tabular}{|l|c|c|c|c|}
\hline \multirow{2}{*}{$\begin{array}{r}\text { Source } \\
\text { Isolated strains }\end{array}$} & \multicolumn{2}{|c|}{ Farms } & \multicolumn{2}{c|}{ Farmers houses } \\
\cline { 2 - 5 } & No./4 & $\%$ & No./7 & $\%$ \\
\hline A.butzleri & 1 & $25.0 \%$ & 1 & $14.28 \%$ \\
A. & 3 & $75.0 \%$ & 4 & $57.14 \%$ \\
cryaerophilus & - & - & 2 & $28.58 \%$ \\
A.skirrowii & & & & \\
\hline Total & 4 & $100.0 \%$ & 7 & $100.00 \%$ \\
\hline
\end{tabular}


Assiut Vet.Med.J. Vol.57No.130July 2011 